\title{
Genetic Linkage of IgG Autoantibody Production in Relation to Lupus Nephritis in New Zealand Hybrid Mice
}

\author{
Timothy J. Vyse, ${ }^{\star}$ Charles G. Drake, ${ }^{\star}$ Stephen J. Rozzo, ${ }^{\star}$ Ellen Roper, ${ }^{\star}$ Shozo Izui, ${ }^{\ddagger}$ and Brian L. Kotzin*\$ \\ *Departments of Pediatrics and Medicine, National Jewish Center for Immunology and Respiratory Medicine, Denver, Colorado 80206; \\ ${ }^{\ddagger}$ Department of Pathology, Centre Médical Universitaire, University of Geneva, Geneva, Switzerland CH-1211; and ${ }^{\S}$ Departments of \\ Immunology and Medicine, University of Colorado Health Sciences Center, Denver, Colorado 80262
}

\begin{abstract}
$F_{1}$ hybrids of New Zealand black (NZB) and New Zealand white (NZW) mice are a model of human systemic lupus erythematosus. These mice develop a severe immune complex-mediated nephritis, in which antinuclear autoantibodies are believed to play the major role. We used a genetic analysis of $\left(\mathrm{NZB} \times \mathrm{NZW} \mathrm{F}_{1} \times \mathrm{NZW}\right.$ backcross mice to provide insight into whether different autoantibodies are subject to separate genetic influences and to determine which autoantibodies are most important in the development of lupus-like nephritis. The results showed one set of loci that coordinately regulated serum levels of IgG antibodies to double-stranded DNA, single-stranded DNA, total histones, and chromatin, which overlapped with loci that were linked to the production of autoantibodies to the viral glycoprotein, gp70. Loci linked with anti-gp70 compared with antinuclear antibodies demonstrated the strongest linkage with renal disease, suggesting that autoantibodies to gp70 are the major pathogenic antibodies in this model of lupus nephritis. Interestingly, a distal chromosome 4 locus, Nba1, was linked with nephritis but not with any of the autoantibodies measured, suggesting that it contributes to renal disease at a checkpoint distal to autoantibody production. (J. Clin. Invest. 1996. 98:1762-1772.) Key words: mouse $\bullet$ lupus $\bullet$ autoimmunity $\bullet$ autoantibodies $•$ genetics
\end{abstract}

\section{Introduction}

The $F_{1}$ hybrids of New Zealand black $(\mathrm{NZB})^{1}$ and New Zealand white (NZW) mice remain one of the best studied models of the human disease, SLE. These mice spontaneously develop an autoimmune disease characterized by the production of antinuclear antibodies and the development of a severe immune complex (IC) glomerulonephritis $(1,2)$. The renal dis-

Address correspondence to Timothy J. Vyse, Division of Basic Sciences, National Jewish Center for Immunology and Respiratory Medicine, 1400 Jackson Street, Denver, CO 80206. Phone: 303-3981097; FAX: 303-398-1225; E-mail: kotzinb@njc.org

Received for publication 17 April 1996 and accepted in revised form 8 August 1996.

1. Abbreviations used in this paper: $\mathrm{cM}$, centiMorgans; dsDNA, double-stranded DNA; IC, immune complex; LOD, $\log _{10}$ likelihood of the odds; NZB, New Zealand black; NZW, New Zealand white; QTL, quantitative trait locus; ssDNA, single-stranded DNA; SSLP, simple sequence length polymorphism.

J. Clin. Invest.

(C) The American Society for Clinical Investigation, Inc. 0021-9738/96/10/1762/11 \$2.00

Volume 98, Number 8, October 1996, 1762-1772 ease is dependent on the production of $\mathrm{IgG}$ autoantibodies. It is currently believed that the most important autoantibody specificity in the pathogenesis of this glomerulonephritis is directed to DNA, especially double-stranded DNA (dsDNA). Elevated levels of circulating anti-DNA antibodies frequently precede the development of nephritis $(3,4)$, and a subset of antibodies with this specificity has been shown to be concentrated in the diseased glomerulus (5-7). Interestingly, circulating immune complexes containing anti-DNA antibodies have been difficult to demonstrate during the course of $(\mathrm{NZB} \times$ $\mathrm{NZW}) \mathrm{F}_{1}$ disease (8). Studies have suggested that immune complexes containing anti-DNA antibodies are instead formed in the kidney, related to the deposition of chromatin and the targeting of IgG autoantibodies to the planted nuclear antigens $(9,10)$. Antibodies to histones and other chromatin antigens may mediate immune complex formation in the kidney through a similar mechanism (10-12). Cross-reactivity with glomerular antigens has been suggested as an additional mechanism by which a subset of anti-DNA antibodies may cause nephritis (13-15).

Investigators also have emphasized the potential pathogenic importance of autoantibodies to the endogenous retroviral envelope glycoprotein, gp70, in the renal disease of (NZB $\times \mathrm{NZW}) \mathrm{F}_{1}$ mice $(16,17)$. Serum gp70, synthesized by hepatic cells, is an acute phase reactant and is present in the serum of all murine strains (18). Only lupus-prone strains, however, make autoantibodies to this self protein and form gp70-antigp70 immune complexes (gp70 IC) (19). $\left(\mathrm{NZB} \times \mathrm{NZW} \mathrm{F}_{1}\right.$ mice demonstrate high serum levels of gp70 IC, and these complexes have been documented in diseased glomeruli (16). In some studies, levels of gp70 IC have been the best correlate of nephritis (19). However, separate studies and multiple investigators have emphasized the greater pathogenicity of $\mathrm{IgG}$ anti-dsDNA antibodies (2).

The $(\mathrm{NZB} \times \mathrm{NZW}) \mathrm{F}_{1}$ mouse model has been utilized to investigate the NZB and NZW genes that predispose to the development of lupus-like autoimmunity. The phenotype of the $\mathrm{F}_{1}$ mice is distinct from that of the two parental strains. For example, neither NZB nor NZW mice regularly develop severe renal disease, produce $\mathrm{IgG}$ autoantibodies to dsDNA or histone, or demonstrate high levels of circulating gp70 IC (1921). Previous analyses of backcross and congenic mice have demonstrated that an important dominant NZW genetic contribution to $\mathrm{F}_{1}$ disease is linked to the $\mathrm{MHC}\left(\mathrm{H} 2^{\mathrm{z}}\right.$ in $\left.\mathrm{NZW}\right)$ and most likely encoded by class II MHC genes (20-24). In the presence of the NZW MHC, heterozygosity for the NZB $\mathrm{MHC}\left(\mathrm{H}_{2}{ }^{\mathrm{d}}\right)$ genes also has been shown to enhance disease expression $(22,25,26)$. Using techniques based on length polymorphism in simple sequence repeats, we and others mapped a dominant NZB contribution to nephritis on distal chromosome 4 (26-28). Additional genetic contributions to disease have been reported, mapping to loci on chromosomes $1,6,7$, 
$10,13,18$, and $19(26,27,29)$. However, only a subset of these loci (on chromosomes 1 and 7), have been linked with disease at currently accepted statistical thresholds. The identity of these non-MHC genes remains unknown. It is also unclear which of the genes enhance disease expression at the level of autoantibody production, and whether any genes influence different autoantibody specificities in a selective manner.

In the present backcross analysis, we investigated dominant NZB loci that are linked with lupus-like glomerulonephritis and/or the production of potentially pathogenic autoantibodies. Surprisingly, a nephritis-contributing gene on chromosome 4 demonstrated little influence on any of the autoantibodies measured. In contrast, other loci were mapped that differentially regulate the production of anti-gp70 versus antinuclear antibodies. Loci linked with the production of gp70 IC showed the greatest linkage with nephritis.

\section{Methods}

Mice. Parental NZB/BINJ and NZW/LacJ mice were obtained from The Jackson Laboratories (Bar Harbor, ME) and were maintained in the animal care facility at The National Jewish Center for Immunology and Respiratory Medicine (Denver, $\mathrm{CO}$ ). The $\mathrm{F}_{1}$ and backcross mice were bred in this facility, and all groups of mice used in the studies were housed in the same room and fed an identical diet. Only female animals were utilized in the present studies.

Evaluation of renal disease and collection of sera and tissues. Mice were evaluated for proteinuria at monthly intervals using tetrachlorophenol-tetrabromosulfophthalein paper (Chemstrip; Boehringer Mannheim Biochemicals, Indianapolis, IN). Urine samples were graded 0 to $3+$, corresponding to approximate protein concentrations as follows: $0 /$ trace $<0.3$ gram/liter; $1+\sim 0.3$ gram/liter; $2+\sim 1$ gram/liter; $3+\sim 3$ gram/liter. Mice with $2+$ or greater proteinuria, on at least two consecutive occasions before 12 mo of age, were designated positive for renal disease. These mice almost always died before 12 months of age from disease as previously described $(21,28)$. Mice that had only negative or trace determinations up to 12 mo of age were determined not to have developed lupus nephritis and were allocated a negative disease phenotype. The study mice were bled (from the tail) at monthly intervals from the age of either 5 or 7 months. The blood was allowed to clot at room temperature, and the serum was stored at $-20^{\circ} \mathrm{C}$ until analyzed for autoantibody levels. Liver and kidney samples were collected from the positive mice at the time of killing or death and from negative mice at the time of elective death at $12 \mathrm{mo}$ of age. The organ samples were frozen at $-70^{\circ} \mathrm{C}$, and DNA was extracted from freshly thawed material as described (30).

Genetic mapping using simple sequence length polymorphisms $(S S L P)$. Oligonucleotides flanking simple sequence repeats were either purchased (Research Genetics, Huntsville, AL) or synthesized at The National Jewish Molecular Resource Center using a DNA synthesizer (392; Applied Biosystems Inc., Foster City, CA). The sequences of the primers used have been described $(31,32)$ and/or can be found at the internet address: http://www-genome.wi.mit.edu/. Amplification of the simple sequence repeats was achieved by the PCR in a PTC-100 thermal cycler (MJ Research, Watertown, MA). PCRs $(20 \mu \mathrm{l})$ generally used 35 cycles of: $30 \mathrm{~s}$ at $94^{\circ} \mathrm{C}, 1 \mathrm{~min}$ at $55^{\circ} \mathrm{C}$, $30 \mathrm{~s}$ at $72^{\circ} \mathrm{C}$. After amplification, $10-15 \mu \mathrm{l}$ of product was loaded onto a $15 \%$ polyacrylamide gel (MiniProtean II; Bio-Rad Laboratories, Richmond, CA) and electrophoresed at $12 \mathrm{~V} / \mathrm{cm}$ for $2-4 \mathrm{~h}$. The PCR products were visualized by ethidium bromide staining and ultraviolet transillumination $(254 \mathrm{~nm})$. The animals were then scored as either BW (heterozygous) or WW (homozygous) for each marker. The positions of the SSLP markers (and genetic loci) with respect to the centromere are given in accordance with the Mouse Chromosome Committee Reports (obtained from Dr. R. Williams via the Internet at http://www.mickey.utmem.edu).
Serological assays. Antibody levels were determined by ELISA. Antibodies to histone, chromatin and single-stranded DNA (ssDNA) were measured as previously described $(21,33)$. Briefly, wells of Immulon II microtiter plates (Dynatech Laboratories, Alexandria, VA) were coated with calf thymus total histones, heat-denatured DNA (Sigma Chemical Co., St. Louis, MO) or chromatin (prepared as described, [34]) at $2.5 \mu \mathrm{g} / \mathrm{ml}$ in PBS, pH 7.2, and postcoated with $1 \mathrm{mg} /$ $\mathrm{ml}$ gelatin. Serum samples were diluted $1: 300$ in PBS with $0.5 \%$ Tween supplemented with $5 \mathrm{mg} / \mathrm{ml}$ bovine $\gamma$ globulins (Sigma Chemical Co.) and gelatin, and added to antigen-coated wells for $90 \mathrm{~min}$. After washing, wells were incubated with peroxidase-labeled antibody for mouse IgG (Kirkegaard \& Perry, Gaithersburg, MD). After $90 \mathrm{~min}$, substrate was added and OD was determined with an automated spectrophotometer (Dynatech Laboratories) at $405 \mathrm{~nm}$. Antibodies to dsDNA were measured as described (35). In brief, plasmid dsDNA (pGEM) was biotinylated and bound to streptavidin-coated microtiter plates. The assay was then performed as above. All samples were also assayed in streptavidin only wells as a control. Minimal cross-reactivity with ssDNA was demonstrated by assaying a ssDNAspecific $m A b$ on each dsDNA plate $(33,36)$. Furthermore, NZW sera containing only IgG autoantibodies to ssDNA do not cross-react in this assay (21). All assays were performed in duplicate, and were quantified against a standard curve obtained with mAbs (36). It was demonstrated previously that there was no cross-reactivity between histone and dsDNA using these assays $(21,36)$.

The production of autoantibodies to gp70 was quantitated as serum levels of gp70-anti-gp70 IC. These complexes were measured by ELISA after precipitation of the serum with polyethylene glycol (average mol wt 6,000$)$ as described $(37,38)$. The results are expressed as $\mu \mathrm{g} / \mathrm{ml}$ of gp70 complexed with anti-gp70 antibodies. Although gp70 is detectable in the serum of nearly all murine strains, only lupus-prone strains produce autoantibodies to gp70 and form gp70 IC (19). It has previously been demonstrated that NZB, NZW, and $(\mathrm{NZB} \times$ $\mathrm{NZW}) \mathrm{F}_{1}$ have similarly high levels of circulating gp70, and that gp70 IC levels are therefore dependent on production of autoantibodies to gp70 (39). The relative excess of gp70 antigen determines that circulating autoantibodies exist in the form of complexes.

Statistical analysis. The association of a particular locus (BW or WW) with renal disease (positive or negative) was quantified by Chisquare $\left(\chi^{2}\right)$ analysis, using a standard $(2 \times 2)$ contingency matrix $(40)$. Linkage with autoantibody levels was analyzed by several means. Firstly, mice were grouped into discrete sets on the basis of specific autoantibody levels and an analysis of extreme phenotypes was performed (41). The extreme phenotype sets, designated low/negative and high/positive, were then compared to the genotype data by $\chi^{2}$ analysis. Separate analyses were performed using antibody levels obtained from mice aged 7 mo and for the peak value determined from serial monthly samples for each individual animal. Linkage with autoantibodies was also sought by using uncategorized autoantibody data and the linkage program, MAPMAKER/QTL $(42,43)$. This program was used to determine quantitative trait loci (QTL) in linkage with serum autoantibody levels. The autoantibody levels were $\log _{10}$ transformed before analysis with MAPMAKER/QTL because this tended to normalize their frequency distribution, which improves the accuracy of MAPMAKER/QTL. Finally, in separate analyses, the mean values for a particular autoantibody were compared in mice homozygous (WW) versus heterozygous (BW) at particular candidate loci. The sample sizes were $>30$ and hence the means were assumed to be normally distributed and confidence intervals determined using a two-tailed analysis.

Because of the multiple hypothesis testing that is inherent in a genome-wide search, a threshold for suggestive linkage was set at loglikelihood of the odds (LOD) $>1.9, P<0.0034\left(\chi^{2}>8.6,1\right.$ degree of freedom [d.f.]), based on the recommendation of Lander and Kruglyak (44). The threshold for probable linkage was LOD $>3.3, P<$ $0.0001\left(\chi^{2}>10.8,1\right.$ d.f. $)$. Loci were also considered to be linked to a trait if a previously mapped locus $(P<0.01)$ was confirmed in the present study (44). 
For the association of anti-dsDNA or gp70 IC with nephritis, autoantibody levels were categorized as low/negative, intermediate, or high/positive, and a $(3 \times 2)$ contingency matrix was constructed using the three phenotype sets. Correlations between different autoantibody specificities were quantified using the nonparametric, Spearman rank correlation coefficient, $r_{\mathrm{s}}$.

\section{Results}

Identification of $N Z B$ and $N Z W$ loci linked with nephritis. To determine the position of loci linked with the development of lupus-like nephritis and death, female $\left(\mathrm{NZB} \times \mathrm{NZW} \mathrm{F}_{1} \times\right.$ NZW backcross mice were bred and followed for the expression of disease as described (28). Animals that had clear evidence of renal disease ( $\geq 2+$ proteinuria on two successive occasions before 12 mo of age) were scored "positive," whereas animals that had no evidence of proteinuria within this time period were allocated to the "negative" group. Nearly all animals with severe proteinuria also died before 12 mo of age, presumably from progressive nephritis and renal failure (21, 28). Individual backcross mice were genotyped at multiple loci by PCR amplification of simple sequence repeats. These mark- ers were predetermined to be polymorphic between NZB (designated $\mathrm{BB}$ ) and NZW (designated WW) strains. (NZB $\times$ $\mathrm{NZW}) \mathrm{F}_{1} \times \mathrm{NZW}$ backcross mice are either heterozygous (designated $\mathrm{BW}$ ) or homozygous (WW) at any given genetic locus.

Initial observations in 60 female $(\mathrm{NZB} \times \mathrm{NZW}) \mathrm{F}_{1} \times \mathrm{NZW}$ backcross mice, which had been genotyped at 74 loci, mapped a single dominant NZB locus that was linked with severe renal disease and death (28). The locus was situated on distal chromosome 4 , and the putative gene was designated Nbal. We have extended these data by including an additional 48 female backcross mice (total 108 mice) of which 60 mice (55\%) exhibited severe lupus-like renal disease. In comparison with the previous study, the backcross mice were mapped with nine more microsatellite markers on chromosomes 1, 4, 13, 16, and 19; a total number of 83 markers were used.

When data from all 108 backcross mice were combined, a total of three loci on chromosome 4 at $\mathrm{Nbal}$, chromosome 16, and chromosome 17 at the MHC were found to be linked with renal disease (Table I). Data from three additional loci, on chromosomes 7, 14, and 19, are shown in Table I because these loci were linked with autoantibody production (see below),

Table I. Loci Linked with Lupus-like Nephritis*

\begin{tabular}{|c|c|c|c|c|c|c|c|}
\hline \multirow[b]{2}{*}{ Position of locus } & \multirow[b]{2}{*}{ Marker ${ }^{\S}$} & \multicolumn{2}{|c|}{ Nephritis } & \multicolumn{2}{|c|}{ No nephritis } & \multirow[b]{2}{*}{$x^{2}$} & \multirow[b]{2}{*}{$P$ value } \\
\hline & & WW & BW & Ww & BW & & \\
\hline Chr.4 (56 cM) & D4Mit11 & 22 & 38 & 28 & 20 & 5.0 & 0.02 \\
\hline Chr.4 (61 cM) & Elp 1 & 20 & 40 & 31 & 17 & $10.5^{*}$ & 0.001 \\
\hline Chr.4 (62 cM) & D4Mit70 & 19 & 41 & 31 & 17 & $11.6^{*}$ & 0.0007 \\
\hline Chr.4 (72 cM) & D4Mit48 & 20 & 40 & 32 & 16 & $11.9^{*}$ & 0.0006 \\
\hline Chr.4 (76 cM) & D4Mit343 & 21 & 39 & 29 & 19 & 6.9 & 0.008 \\
\hline Chr.16 (14 cM) & D16Mit57 & 39 & 21 & 24 & 24 & 2.5 & 0.1 \\
\hline Chr.16 (32 cM) & D16Mit5 & 42 & 18 & 20 & 28 & $8.7^{*}$ & 0.003 \\
\hline Chr.16 (44cM) & D16Mit6 & 39 & 21 & 23 & 25 & 3.2 & 0.08 \\
\hline Chr.17 (18 cM) & D17Mit16 & 22 & 38 & 33 & 15 & $11.0^{*}$ & 0.0009 \\
\hline Chr.17 (19 cM) & Tnfa & 19 & 41 & 33 & 15 & $14.7^{*}$ & 0.0001 \\
\hline Chr.17 (24 cM) & D17Mit10 & 20 & 40 & 33 & 15 & $13.4^{*}$ & 0.0003 \\
\hline Chr.7 (50 cM) & D7Mit125 & 26 & 34 & 29 & 18 & 3.5 & 0.06 \\
\hline Chr.7 (52 cM) & D7Mit7 & 24 & 36 & 27 & 19 & 3.6 & 0.06 \\
\hline Chr.7 (70 cM) & $D 7 N d s 4$ & 28 & 32 & 29 & 17 & 2.8 & 0.09 \\
\hline Chr.14 (3 cM) & D14Mit1 & 37 & 23 & 20 & 28 & 4.3 & 0.04 \\
\hline Chr.14 (22 cM) & D14Mit4 & 36 & 24 & 19 & 29 & 4.5 & 0.03 \\
\hline Chr.14 (27 cM) & D14Mit5 & 36 & 23 & 19 & 28 & 4.4 & 0.03 \\
\hline Chr.19 (33 cM) & D19Mit13 & 31 & 27 & 22 & 25 & 0.3 & 0.6 \\
\hline Chr.19 (38 cM) & D19Mit11 & 29 & 28 & 21 & 26 & 0.4 & 0.5 \\
\hline Chr.19 (49 cM) & D19Mit6 & 30 & 24 & 29 & 19 & 0.2 & 0.6 \\
\hline
\end{tabular}

*Loci listed showing at least suggestive linkage $(P<0.0034)$ with nephritis are shown in the upper half of the table. The three loci listed in the lower part of the table were all linked with autoantibody production but not nephritis, and are shown to allow estimates of statistical power. Of the remaining 53 loci situated at least $10 \mathrm{cM}$ from the loci listed above, the chi-square values were distributed as follows: $0-1, n=39 ; 1-2, n=5 ; 2-3, n=3 ; 3-4$, $n=3$; and $>4, n=1$. The locus with chi-square $>4$ was D1Mit155 $(1,108)$, chi-square $=5.4 .{ }^{\ddagger}$ The position of the markers is given as distance from the centromere in cM. ${ }^{\S}$ The additional microsatellite markers used in this study, in comparison with the previous study (28), are D1Mit50 (1,52), D1Mit115 (1, 97), D1Mit115 (1,108), D4Mit72 (4,62), D4Mit179 (4,69), D4Mit343 (4,76), D7Mit125 (7,50), D13Mit73 (13,53), D16Mit57 (16,14), D19Mit28 (19,12), D19Mit13 (19,33), and DXMit16 (X,42). 
but associations with nephritis were not significant at the $P<$ 0.0034 level. Of the nephritis-relevant loci, the previously described site on chromosome 4, Nbal, (28) remained significant, with the strongest linkage between Elp1 (62 cM [centiMorgans] from the centromere) and D4Mit $48(72 \mathrm{cM})$. Although a decline in the strength of the linkage was found with a more distal marker on chromosome 4, (D4Mit343 [76 cM]), the inclusion of additional mice did not allow more accurate localization of Nbal. Of the loci mapped, the strongest overall correlation with nephritis was demonstrated at the MHC. Mice which were heterozygous $(\mathrm{BW})$ at the $\mathrm{MHC}\left(\mathrm{H}^{\mathrm{d} / \mathrm{z}}\right)$ were more likely $(P=0.0001)$ to develop severe nephritis than those mice which were homozygous (WW) at the $\mathrm{MHC}\left(\mathrm{H}^{z / z}\right)$. This result was noteworthy because it was previously shown that the NZW MHC was a potent, dominant contribution to disease in $(\mathrm{NZB} \times \mathrm{NZW}) \mathrm{F}_{1} \times \mathrm{NZB}$ backcross mice $(20,21,23,24)$.

An NZW locus on chromosome 16 showed weaker linkage with nephritis compared to the loci described above. The strongest linkage $(P=0.0031)$ was with D16Mit5 $(32 \mathrm{cM}$ distal from the centromere). Of 53 loci that were at least $10 \mathrm{cM}$ from the markers significantly linked with nephritis, only two showed a trend for an association with nephritis $(0.05>P>$ $0.01)$ : one was an NZB allele on distal chromosome $1,108 \mathrm{cM}$ from the centromere, and the other was an NZW allele on chromosome 14, $22 \mathrm{cM}$ from the centromere.

Analysis of autoantibody phenotypes. Autoantibody production was also investigated in $98(\mathrm{NZB} \times \mathrm{NZW}) \mathrm{F}_{1} \times \mathrm{NZW}$ backcross mice. We focused on autoantibodies that have been previously implicated in the pathogenesis of nephritis, including IgG autoantibodies to dsDNA, histone, chromatin and ssDNA and autoantibodies to gp70 in the form of gp70 IC $(2,17$, $21,22)$. It should be emphasized that since NZB, NZW, $F_{1}$, and backcross mice have similar serum levels of gp70, the level of gp70-anti-gp70 IC reflects the production of IgG autoantibodies to gp70 (39). For each mouse, two values for each serological parameter were utilized for the analysis of genetic associa- tions. Serum levels of autoantibodies at 7 mo of age were chosen because the great majority of female $(\mathrm{NZB} \times \mathrm{NZW}) \mathrm{F}_{1}$ mice have elevated levels of antinuclear antibodies and gp70 IC by this age, whereas parental NZB or NZW mice are usually serologically negative at this age $(1,19,21,45)$. The second value used in the genetic analyses was the highest autoantibody level for a particular mouse found in serial monthly samples up to 12 mo of age.

Fig. 1 shows that there was a wide spread of autoantibody levels among backcross animals at 7 mo of age. Mice were classified as low/negative or high-positive for each of the autoantibody specificities measured. It is emphasized that this was done without prior knowledge of the genotype. In general, for each autoantibody measured there was a group of mice $(\sim$ lower tertile) which had very low or undetectable circulating levels of autoantibody. These are delineated in Fig. 1 by data points below the lower horizontal bar. Autoantibody levels in these backcross mice were similar to values for parental agematched female NZW mice (Fig. 1). The upper cut-offs were chosen nearest to the upper tertile for two reasons: firstly, so that a similar number of mice were included in the high phenotype group for all the autoantibodies measured; and secondly, so that values for the high/positive group of backcross mice corresponded to autoantibody levels in female $(\mathrm{NZB} \times \mathrm{NZW}) \mathrm{F}_{1}$ controls. A similar method was used when considering peak autoantibody levels (data not shown).

To ascertain whether there were distinct genetic contributions to the production of different autoantibodies specificities, correlations between the different autoantibody levels were determined. A strong correlation was apparent for antihistone antibody levels and anti-dsDNA antibody levels (Spearman rank correlation coefficient, $r_{\mathrm{s}}=0.62, P<1 \times$ $\left.10^{-6}\right)$. Similar results $\left(r_{\mathrm{s}} \sim 0.6\right.$ to 0.7$)$ were obtained when antichromatin antibodies were compared to anti-dsDNA and antihistone antibodies. In contrast, the correlation was weaker $\left(r_{\mathrm{s}}=0.47, P<1 \times 10^{-6}\right)$ for IgG anti-ssDNA versus IgG anti-
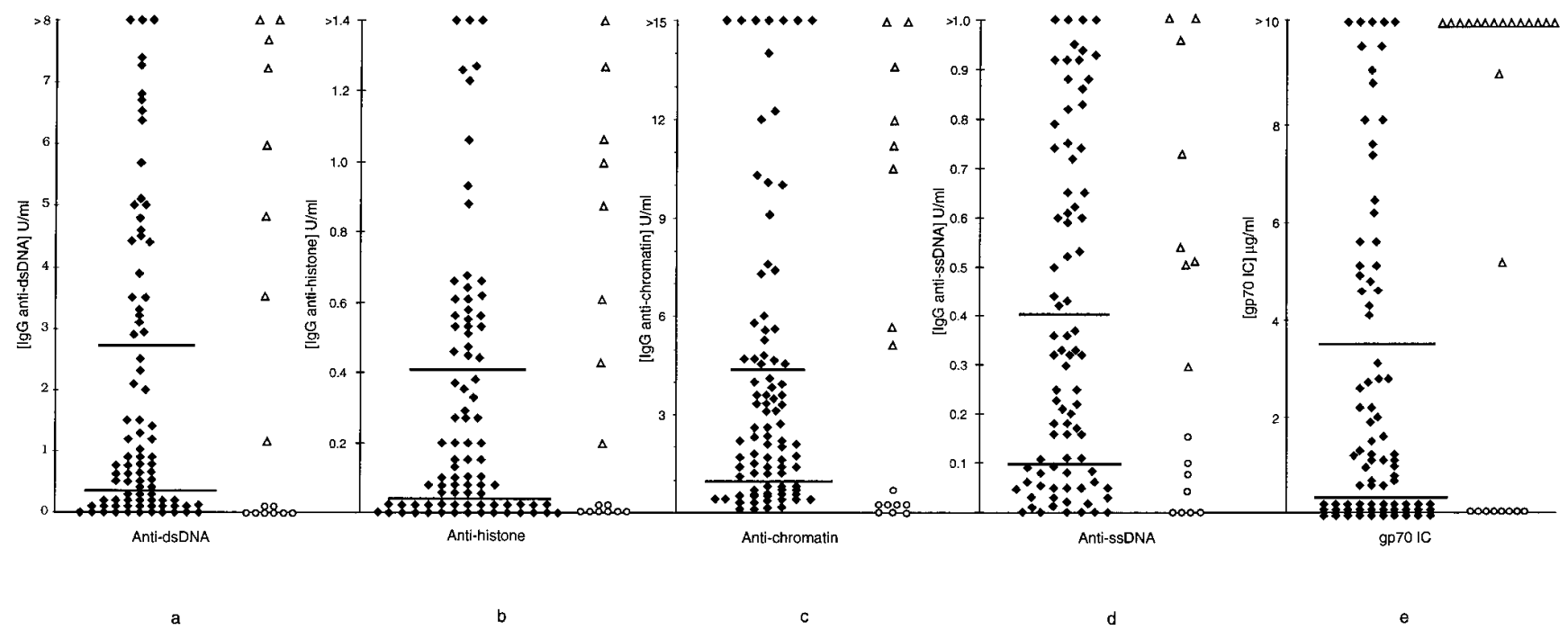

Figure 1. Serum levels of autoantibody levels in individual mice at $7 \mathrm{mo}$. Levels are shown for: $(a) \operatorname{IgG}$ anti-dsDNA antibodies $(U / m l) ;(b) \operatorname{IgG}$ antihistone antibodies $(\mathrm{U} / \mathrm{ml}) ;(c) \mathrm{IgG}$ antichromatin antibodies $(\mathrm{U} / \mathrm{ml}) ;(d) \mathrm{IgG}$ anti-ssDNA antibodies $(\mathrm{U} / \mathrm{ml})$; and $(e)$ anti-gp70/gp70 immune

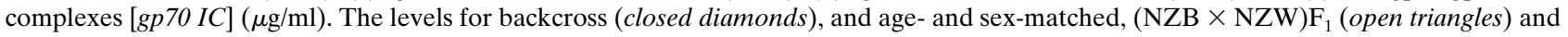
NZW (open circles) mice, are given in each panel. Backcross mice with autoantibody levels below the lower horizontal bar were assigned a low/ negative phenotype with respect to the autoantibody measured, whereas mice with autoantibody levels above the upper horizontal bar were assigned a high autoantibody phenotype. 
Table II. Linkage of Particular Loci with Autoantibody Production by Analysis of Extreme Phenotypes of Mice at 7 mo of Age (A) and Peak Levels Before 12 mo of Age (B)

\begin{tabular}{|c|c|c|c|c|c|c|c|}
\hline \multirow[b]{2}{*}{$\begin{array}{l}\text { Position of } \\
\text { locus }\end{array}$} & \multirow[b]{2}{*}{$\begin{array}{l}\text { Microsatellite } \\
\text { marker }\end{array}$} & \multirow[b]{2}{*}{$\begin{array}{l}\text { Direction of } \\
\text { linkage }\end{array}$} & \multicolumn{5}{|c|}{ Significance of association $\left(\chi^{2}\right)$} \\
\hline & & & $\underset{\text { anti-dsDNA* }}{\mathrm{IgG}}$ & $\begin{array}{c}\mathrm{IgG} \\
\text { antihistone* }\end{array}$ & $\begin{array}{c}\operatorname{IgG} \\
\text { antichromatin* }\end{array}$ & $\underset{\text { anti-ssDNA* }}{\mathrm{IgG}}$ & gp70 IC* \\
\hline \multicolumn{8}{|l|}{ A. Mice aged $7 \mathrm{mo}$} \\
\hline Chr.4 (62 cM) & D4Mit70 & $\mathrm{BW}>\mathrm{WW}$ & 0.24 & 0.42 & 0.90 & 1.2 & 0.46 \\
\hline Chr.4 (72 cM) & D4Mit48 & $\mathrm{BW}>\mathrm{WW}$ & 0.05 & 0.24 & 0.49 & 0.74 & 3.9 \\
\hline Chr.4 (76 cM) & D4Mit343 & $\mathrm{BW}>\mathrm{WW}$ & 0.30 & 0.10 & 0.45 & 0.68 & 5.2 \\
\hline Chr.7 (52 cM) & D7Mit7 & $\mathrm{BW}>\mathrm{WW}$ & $17.0^{\|}$ & $14.6^{\S}$ & 5.0 & 5.9 & 5.7 \\
\hline Chr.14 (22 cM) & D14Mit4 & $\mathrm{WW}>\mathrm{BW}$ & 0.02 & 0.19 & 0.61 & 0.01 & 6.9 \\
\hline Chr.16 (32 cM) & D16Mit5 & $\mathrm{WW}>\mathrm{BW}$ & $11.4^{\S}$ & $8.7^{\ddagger}$ & 4.2 & 5.8 & 4.8 \\
\hline Chr.17 (MHC) & $\operatorname{Tnf} \alpha$ & $\mathrm{BW}>\mathrm{WW}$ & 0.31 & 1.5 & 1.5 & 0.5 & $12.8^{\S}$ \\
\hline Chr.19 (38 cM) & D19Mit11 & $\mathrm{BW}>\mathrm{WW}$ & 3.2 & 4.4 & $9.2^{\ddagger}$ & $12.8^{\S}$ & 1.2 \\
\hline \multicolumn{8}{|c|}{ B. Analysis of peak autoantibody levels } \\
\hline Chr.4 (62 cM) & D4Mit70 & $\mathrm{BW}>\mathrm{WW}$ & 0.76 & 0.13 & 0.02 & 0.90 & 0.28 \\
\hline Chr.4 (72 cM) & D4Mit48 & $\mathrm{BW}>\mathrm{WW}$ & 0.09 & 0.60 & 0.02 & 0.43 & 0.62 \\
\hline Chr.4 (76 cM) & D4Mit343 & $\mathrm{BW}>\mathrm{WW}$ & 0.09 & 0.25 & 0.23 & 0.20 & 1.8 \\
\hline Chr.7 (52 cM) & D7Mit7 & $\mathrm{BW}>\mathrm{WW}$ & $11.7^{\S}$ & 5.8 & $9.4^{\ddagger}$ & $13.8^{\S}$ & 4.5 \\
\hline Chr.14 (22cM) & D14Mit4 & $\mathrm{WW}>\mathrm{BW}$ & 0.01 & 0.01 & 0.43 & 0.00 & $8.8^{\ddagger}$ \\
\hline Chr.16 (32 cM) & D16Mit5 & $\mathrm{WW}>\mathrm{BW}$ & 5.7 & 8.4 & 4.8 & 4.7 & 5.6 \\
\hline Chr.17 (MHC) & $\operatorname{Tnf} \alpha$ & $\mathrm{BW}>\mathrm{WW}$ & 0.62 & 0.91 & 1.2 & 0.82 & $12.2^{\S}$ \\
\hline Chr.19 (38 cM) & D19Mit11 & $\mathrm{BW}>\mathrm{WW}$ & 6.5 & 2.8 & 5.4 & 7.1 & 3.8 \\
\hline
\end{tabular}

*The numbers of mice categorized as high and low/negative, respectively, were 28,31 - dsDNA; 30,28 - histone; 29,26 - chromatin; 32,30 - ssDNA; 26,30 - gp70 IC at 7 mo and 32,29 - dsDNA; 31,29 - histone; 29,28 - chromatin; 31,30 -ssDNA and 31,28 - gp70 IC for peak levels; ${ }^{\ddagger} P<3.4 \times 10^{-3}$; ${ }^{\S} P<1.0 \times 10^{-3} ; \| P<1.0 \times 10^{-4}$.

dsDNA antibodies, mostly related to a group of mice with high levels of anti-ssDNA antibodies but low levels of anti-dsDNA antibodies. These data are certainly consistent with previous studies showing that NZW mice may produce anti-ssDNA antibodies, but almost none produce autoantibodies to dsDNA (21). Finally, when anti-gp70 IC concentrations were plotted against anti-dsDNA levels the correlation was much weaker $\left(r_{\mathrm{s}}=0.28, P=0.007\right)$, suggesting the possibility that different genetic loci influence their production.

Identification of loci linked with autoantibody production. Linkage between genotype and autoantibody phenotype, as determined by extreme phenotype analysis, are shown in mice at 7 mo of age (Table II $A$ ), and for peak autoantibody values (Table II $B$ ). Linkage was determined by $\chi^{2}$ analysis. Results obtained with MAPMAKER/QTL, in which each trait is handled as a continuous variable (i.e., without categorization into phenotype sets), are shown in Table III, and linkage was expressed as an LOD score at each locus. The results obtained by both forms of statistical analysis were corroborative, although there was a trend for stronger linkage with the QTL analysis. One of the strongest linkages mapped was between gp70 IC concentrations and the NZB haplotype at the MHC, $\left(\chi^{2}=\right.$ $12.8, P=4 \times 10^{-4}$; LOD $=3.57, P=5.1 \times 10^{-5}$, for seven month values and $\chi^{2}=12.2, P=5 \times 10^{-4}$; LOD $=4.02, P=$ $1.6 \times 10^{-5}$ for peak values). Interestingly, there was no statistically significant influence of MHC type on the production of antinuclear autoantibodies, analyzing either 7 mo (Table II) or peak values (Table III). It is possible that a type II error was made so that a weak association may have been missed. However, the strength of this genetic contribution to anti-gp70 pro- duction far outweighs any influence that the MHC might have on antinuclear autoantibody production. This is of particular interest in view of the linkage between heterozygosity at the MHC and the development of nephritis (Table I).

Non-MHC loci were also found to have linkage with autoantibody production, particularly with the levels of antinuclear autoantibodies. The two loci with the strongest linkage were on chromosome 7 (at $52 \mathrm{cM}$ from the centromere) and on chromosome 16 (at $32 \mathrm{cM}$ from the centromere). The former was due to the influence of an NZB allele, whereas the latter was the effect of homozygous NZW alleles. Linkage was independent of whether 7 mo data (Tables II $A$ and III $A$ ) or peak serological data (Tables II $B$ and III $B$ ) were studied and were present (at least as a strong trend) for all the different antinuclear antibody specificities measured. Although statistical significance was not reached, these two loci may have a minor influence on anti-gp70 production. The same locus on chromosome 16 was also found to be linked with nephritis and the bias was in the same direction, namely NZW homozygosity (see Table I). The NZB allele on chromosome 7 may have a weak influence on nephritis too, but the $P$ value for this locus was below the significance cut-off. There was also an NZW locus on chromosome 14 (22 cM from the centromere) that showed suggestive linkage with anti-gp70 production $\left(\chi^{2}=8.74, P=\right.$ $3 \times 10^{-3}$; LOD $=2.02, P=2.3 \times 10^{-3}$ for peak antibody levels). As shown in Table I, this locus showed a trend for linkage with nephritis $(P=0.035)$. Importantly, this chromosome 14 locus had no apparent influence on antinuclear antibody production. An additional non-MHC locus $(\mathrm{BW}>\mathrm{WW})$ on chromosome 19 (38 cM from the centromere), was linked with anti- 
Table III. Linkage of Loci with Autoantibody Production Determined by QTL Analysis at 7 mo of Age (A) and Peak Levels Before 12 mo of Age (B)

\begin{tabular}{|c|c|c|c|c|c|c|c|}
\hline \multirow[b]{2}{*}{$\begin{array}{l}\text { Position of } \\
\text { locus }\end{array}$} & \multirow[b]{2}{*}{$\begin{array}{c}\text { Microsatellite } \\
\text { marker }\end{array}$} & \multirow[b]{2}{*}{$\begin{array}{l}\text { Direction of } \\
\text { linkage }\end{array}$} & \multicolumn{5}{|c|}{ Significance of association (LOD score) } \\
\hline & & & 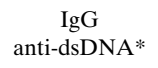 & $\begin{array}{c}\mathrm{IgG} \\
\text { antihistone* }\end{array}$ & $\begin{array}{c}\mathrm{IgG} \\
\text { antichromatin* }\end{array}$ & $\underset{\text { anti-ssDNA* }}{\mathrm{IgG}}$ & gp 70 IC* \\
\hline \multicolumn{8}{|l|}{ A. Mice aged $7 \mathrm{mo}$} \\
\hline Chr.4 (62 cM) & D4Mit70 & $\mathrm{BW}<\mathrm{WW}$ & 0.28 & 0.06 & 0.84 & 0.03 & 0.03 \\
\hline Chr.4 (72 cM) & D4Mit48 & $\mathrm{BW}<\mathrm{WW}$ & 0.34 & 0.06 & 0.53 & 0.04 & 0.03 \\
\hline Chr.4 (76 cM) & D4Mit343 & $\mathrm{BW}<\mathrm{WW}$ & 0.33 & 0.07 & 0.54 & 0.03 & 0.40 \\
\hline Chr.7 (52 cM) & D7Mit7 & $\mathrm{BW}<\mathrm{WW}$ & $2.3^{\S}$ & $3.1^{\ddagger}$ & 1.2 & 1.8 & 1.5 \\
\hline Chr.14 (22 cM) & D14Mit4 & $\mathrm{WW}<\mathrm{BW}$ & 0.00 & 0.00 & 0.04 & 0.00 & 1.8 \\
\hline Chr.16 (32 cM) & D16Mit5 & $\mathrm{WW}<\mathrm{BW}$ & $2.1^{+}$ & $3.1^{\S}$ & $2.1^{\ddagger}$ & $2.7^{\S}$ & 0.6 \\
\hline Chr.17 (MHC) & $\operatorname{Tnf} \alpha$ & $\mathrm{BW}<\mathrm{WW}$ & 0.10 & 0.04 & 0.07 & 0.24 & 3.6 \\
\hline Chr.19 (38 cM) & D19Mit11 & $\mathrm{BW}>\mathrm{WW}$ & 0.26 & 1.3 & 1.5 & $2.5^{\S}$ & 0.65 \\
\hline \multicolumn{8}{|c|}{ B. Analysis of peak autoantibody levels } \\
\hline Chr.4 (62 cM) & D4Mit70 & $\mathrm{BW}<\mathrm{WW}$ & 0.12 & 0.12 & 0.68 & 0.00 & 0.92 \\
\hline Chr.4 (72 cM) & D4Mit48 & $\mathrm{BW}<\mathrm{WW}$ & 0.25 & 0.12 & 0.17 & 0.02 & 0.80 \\
\hline Chr.4 (76 cM) & D4Mit343 & $\mathrm{BW}<\mathrm{WW}$ & 0.12 & 0.14 & 0.17 & 0.00 & 0.80 \\
\hline Chr.7 (52 cM) & D7Mit7 & $\mathrm{BW}<\mathrm{WW}$ & $3.1^{\S}$ & 1.4 & $1.9^{\ddagger}$ & $1.9^{\ddagger}$ & 0.5 \\
\hline Chr.14 (22 cM) & D14Mit4 & $\mathrm{WW}<\mathrm{BW}$ & 0.01 & 0.00 & 0.00 & 0.00 & $2.0^{\ddagger}$ \\
\hline Chr.16 (32 cM) & D16Mit5 & $\mathrm{WW}<\mathrm{BW}$ & 1.8 & 1.6 & 1.2 & 1.2 & 1.1 \\
\hline Chr.17 (MHC) & $\operatorname{Tnf} \alpha$ & $\mathrm{BW}<\mathrm{WW}$ & 0.03 & 0.06 & 0.30 & 0.30 & $4.0^{\|}$ \\
\hline Chr.19 (38 cM) & D19Mit11 & $\mathrm{BW}<\mathrm{WW}$ & 1.2 & 1.8 & 0.94 & $4.1^{\|}$ & 1.3 \\
\hline
\end{tabular}

*Analysis of data from between 92 and 98 backcross mice studied serologically; ${ }^{\ddagger} P<3.4 \times 10^{-3} ;{ }^{\S} P<1.0 \times 10^{-3} ; \| P<1.0 \times 10^{-4}$.

nuclear autoantibody production, but not with nephritis. In general, the different antinuclear specificities were subject to the same genetic influences. However, it was noted that the chromosome 19 locus had the strongest linkage with IgG antissDNA antibody production (Table III $B$ ).

To further illustrate the selective effect of particular loci on autoantibody production, anti-dsDNA and gp70 IC levels for all the mice were plotted on the basis of whether they were BW or WW at the linked chromosome 7, chromosome 14, or MHC loci (Fig. 2). For the chromosome 7 locus, the mean level of anti-dsDNA antibody activity in WW mice was $0.91 \pm 0.24$ SEM U/ml compared with 2.85 $\pm 0.80 \mathrm{SEM} \mathrm{U/ml} \mathrm{in} \mathrm{BW} \mathrm{mice}$ (Fig. $2 a$ ). The means were compared using the central limit theorem and were significantly different $(P=0.01)$. When gp70 IC concentrations were studied (Fig. $2 d$ ), a small but not significant effect of the chromosome 7 locus was identified $(\mathrm{BW}=3.55 \pm 0.74 \mathrm{U} / \mathrm{ml}, \mathrm{WW}=2.15 \pm 0.58 \mathrm{U} / \mathrm{ml}, P=0.07)$. The powerful influence of the MHC on gp70 IC production (Fig. $2 \mathrm{f}$ ) was again corroborated $(\mathrm{BW}=4.23 \pm 0.77 \mu \mathrm{g} / \mathrm{ml}$, $\left.\mathrm{WW}=1.18 \pm 0.35 \mu \mathrm{g} / \mathrm{ml}, P=2 \times 10^{-4}\right)$. In contrast, no influence of MHC type on anti-dsDNA production was identified (Fig. 2 c). Similar to MHC, the chromosome 14 locus also showed a significant influence on gp70 IC but not anti-dsDNA antibodies, which was reflected in the mean levels (Fig. 2, b and $e$ ).

The effect of chromosome 4 on autoantibody production. It was striking that the NZB locus on distal chromosome 4, which was confirmed to have linkage with nephritis (Table I), had little or no apparent influence on autoantibody production. There was a weak association of the most distal marker (distal to Nbal) studied on chromosome 4 (D4Mit343, $76 \mathrm{cM}$ ) with gp70 IC for mice aged 7 mo (Table II $A$ ), but this was not present when peak values were studied (Table II $B$ ) or by QTL analysis (Table III). Furthermore, no linkage with any locus on distal chromosome 4 was found with any type of antinuclear autoantibody production. A comparison of mean levels in mice heterozygous versus homozygous at Elp1 also showed no differences in anti-dsDNA or anti-gp70 antibody levels (for $\mathrm{BW}$ vs WW mice, mean levels of anti-dsDNA $=1.60 \pm 0.36$ vs $1.92 \pm 0.58$, and gp70 IC $=2.83 \pm 0.60$ vs $2.16 \pm 0.69$, respectively). Together, these results suggest that the mechanism by which the chromosome 4 NZB allele enhances nephritis is mediated at a level separate from autoantibody production.

Association of nephritis with anti-gp 70 versus anti-dsDNA autoantibodies. The results of these genetic analyses suggested that the loci that influenced anti-gp70 production had a stronger link with the development of nephritis compared with loci that were associated with antinuclear antibody production. The association of nephritis with serum anti-gp70 versus anti-dsDNA autoantibodies is shown in Table IV and in Fig. 2 above (diseased vs disease-free mice are shown as solid versus open symbols, respectively). There was a definite bias toward higher circulating anti-dsDNA antibodies occurring in nephritic mice, which did not reach statistical significance. In contrast, the association of high gp70 IC with nephritis was highly significant. The same conclusion was reached when these autoantibody data were analyzed as a continuous variable.

\section{Discussion}

Autoantibodies play a major role in the pathogenesis of lupus nephritis in $(\mathrm{NZB} \times \mathrm{NZW}) \mathrm{F}_{1}$ mice. The aim of the current 


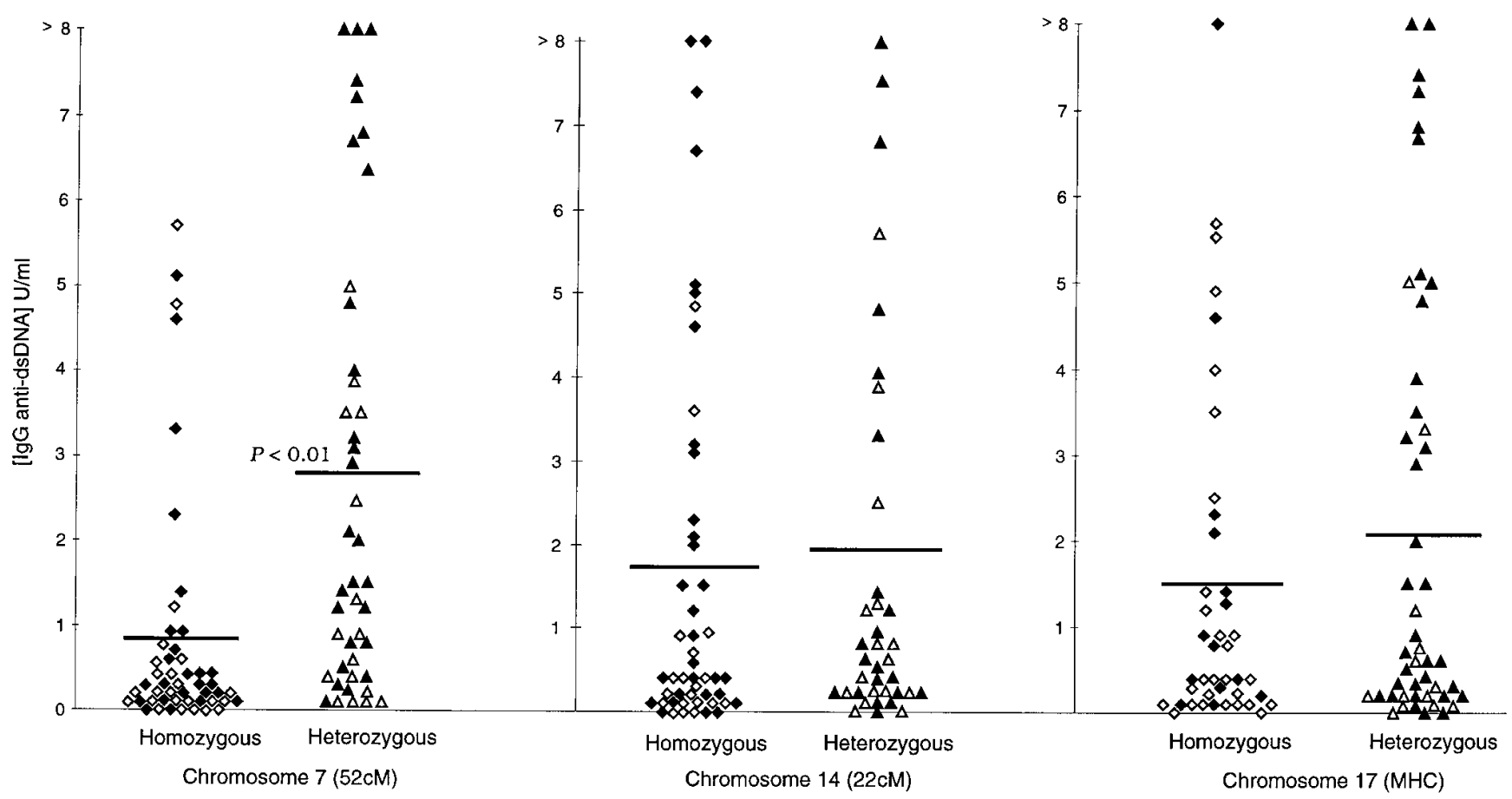

b

c

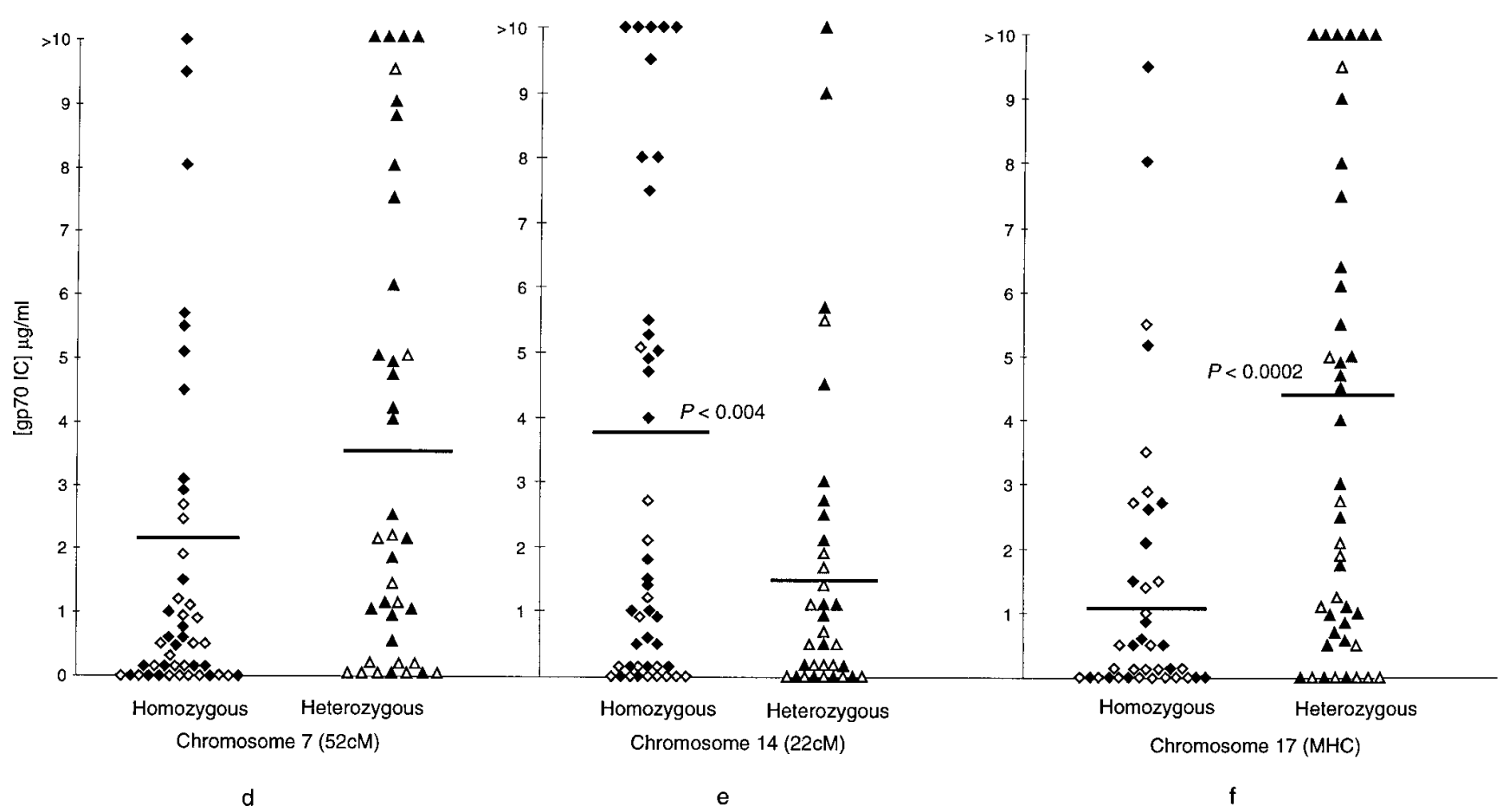

Figure 2. IgG anti-dsDNA antibody and gp70 IC levels in relation to genotype at loci on chromosomes 7, 14, and 17. The levels of IgG antidsDNA antibodies in individual mice are shown separated on the basis of whether the animals were homozygous (WW, diamond-shaped symbols) or heterozygous (BW, triangular symbols) as determined by: (a) the SSLP marker, D7Mit7 (chromosome 7, $52 \mathrm{cM}$ from the centromere); (b) the SSLP marker, D14Mit4 (chromosome 14, $22 \mathrm{cM}$ from the centromere); (c) the SSLP marker in TNF $\alpha$ (chromosome 17, MHC-19 cM from the centromere). The levels of gp70 IC in individual mice are shown separated on the basis of whether the animals were homozygous (WW, diamond-shaped symbols) or heterozygous (BW, triangular symbols) as determined by: $(d)$ the SSLP marker, D7Mit7 (chromosome 7, $52 \mathrm{cM}$ from the centromere); (e) the SSLP marker, D14Mit4 (chromosome 14, $22 \mathrm{cM}$ from the centromere); and ( $f$ ) the SSLP marker in TNF $\alpha$ (chromosome $17, M H C-19 \mathrm{cM}$ from the centromere). In all figures animals that developed severe nephritis are shown as solid symbols, and mice that remained healthy for the first 12 mo of life are depicted with open symbols. 
Table IV. Association of Autoantibodies to dsDNA or gp70 with Nephritis

\begin{tabular}{lccc}
\hline & \multicolumn{2}{c}{ Number of mice } & \\
\cline { 2 - 3 } & Nephritis & No nephritis & $x^{2}$ \\
\hline Anti-dsDNA (U/ml) & & & $3.9^{*}$ \\
$\quad$ low $(<0.4)$ & $14^{\S}$ & 18 & \\
$\quad$ intermediate $(0.4-2.5)$ & 20 & 12 & \\
high $(>2.5)$ & 20 & 8 & $13.6^{\ddagger}$ \\
gp70 IC $(\mu \mathrm{g} / \mathrm{ml})$ & & & \\
$\quad$ low $(<0.5)$ & 10 & 20 & \\
intermediate $(0.5-3.5)$ & 21 & 12 & \\
high $(>3.5)$ & 23 & 3 & \\
\end{tabular}

* $P=0.14$ as determined by a $3 \times 2$ contingency table. ${ }^{\ddagger} P=0.001$ as determined by a $3 \times 2$ contingency table. ${ }^{\S}$ Of the 14 mice with nephritis before 12 mo of age, but negligible quantities of detectable serum IgG anti-dsDNA antibodies, nine had either intermediate or high levels of circulating gp70 IC, three had intermediate levels of IgG anti-chromatin and $\mathrm{IgG}$ antihistone antibodies, and two had no significant detectable circulating autoantibodies.

study was to investigate genetic loci linked with the development of renal disease in $(\mathrm{NZB} \times \mathrm{NZW}) \mathrm{F}_{1} \times \mathrm{NZW}$ backcross mice and to compare these disease-associated loci with those that control the production of potentially pathogenic autoantibodies. Previous analyses of NZB recombinant inbred strains have shown that certain NZB autoimmune traits are inherited independently $(46,47)$, but our results are the first to map loci that are differentially linked with separate autoantibody specificities in $(\mathrm{NZB} \times \mathrm{NZW}) \mathrm{F}_{1}$ mice. Because of this selective genetic control, the data also point to particular autoantibody specificities that are most important in the pathogenesis of renal disease. Finally, we have demonstrated that the locus, $\mathrm{Nba1}$, on chromosome 4 is likely to exert its effect at an etiologic checkpoint distal to autoantibody production.

MHC type was confirmed to have the strongest linkage with renal disease, and the strongest genetic influence on gp70 IC levels. $\mathrm{H} 2^{\mathrm{d} / \mathrm{z}}$ backcross mice had a significantly higher frequency of severe proteinuria and death, as well as markedly higher levels of gp70 IC compared with $\mathrm{H}^{2 / z}$ mice. In contrast to the effect on gp70 autoantibodies, heterozygosity at the MHC appeared to have little influence on the production of any of the antinuclear antibodies measured. Although a weak effect of MHC composition on antinuclear antibodies cannot be discounted, if present at all, it would be substantially weaker than the association of the MHC and anti-gp70 levels. Other investigators have previously demonstrated the importance of the NZB H $2^{\mathrm{d}}$ haplotype, in the context of $\mathrm{H}^{\mathrm{z}}$ from the NZW, on both disease and autoantibody production (22, $23,25,26,48)$. The $\mathrm{H} 2^{\mathrm{d} / \mathrm{z}}$ haplotype has been associated with autoantibodies to dsDNA (25), and gp70 IC $(22,23,48)$, and more recently shown to be in linkage with antichromatin antibodies (26). In contrast, we found no linkage of $\mathrm{H} 2^{\mathrm{d} / \mathrm{z}}$ with any of the antinuclear antibodies measured. It is possible that stronger linkage with the anti-gp70 response, compared with the antinuclear response, would have been found in the previous linkage study, but anti-gp70 was not measured concurrently. In this regard, it is of interest that in one earlier study of backcross mice, $\mathrm{H} 2^{\mathrm{d} / \mathrm{z}}$ (versus $\mathrm{H} 2^{\mathrm{z} / \mathrm{z}}$ ) was more strongly associated with anti-gp70 compared with anti-dsDNA antibodies (48). The difference in results compared to the previous linkage study (26) may also reflect the action of background genes since linkage was previously found in an NZB/NZW $\mathrm{F}_{2}$ intercross. In contrast with a backcross, an $\mathrm{F}_{2}$ intercross is subject to the influence of recessive NZW and NZB alleles. It is also theoretically possible that discrepancies reflect the nature of the antigen used in assaying for antinuclear autoantibodies. It is noteworthy that antibodies to dsDNA, ssDNA, total histones, and chromatin were all measured in the present study and none appeared to be influenced by MHC type, whereas antibody analyses were more limited in previous studies.

It is of interest that past studies of MHC contributions to murine lupus have not been able to demonstrate a selective influence on particular autoantibody specificities $(22,25)$. Similar findings have also been reported in other spontaneous autoimmune models such as the nonobese diabetic (NOD) model of type 1 diabetes mellitus. Thus, the NOD I-A molecule appears to be important for the control of autoimmune responses, but studies thus far have not demonstrated a selective effect on particular relevant specificities (49). Furthermore, the introduction of I-E molecules in murine lupus or NOD mice also has resulted in a generalized decrease in autoimmunity rather than selective changes in specific responses (50-53).

The mechanism by which MHC heterozygosity influences the anti-gp70 autoimmune response is unknown. Since CD4 ${ }^{+}$ $\mathrm{T}$ cells are required for $\mathrm{IgG}$ autoantibody responses and the development of renal disease (54), it is believed that class II MHC molecules underlie the association. Whether the NZB contribution depends on $\mathrm{I}-\mathrm{A}^{\mathrm{d}}$ or $\mathrm{I}-\mathrm{E}^{\mathrm{d}}$ molecules, or whether hybrid I-A $A^{d / z}$ or $I-E^{d / z}$ molecules (55) are involved is currently unknown. In this regard, it is of interest that other MHC haplotypes appear to be similar to $\mathrm{H} 2^{\mathrm{d}}$ in enhancing disease expression. For example, in a backcross analysis of NZB/NZW recombinant inbred mice, heterozygosity for $\mathrm{H} 2^{\mathrm{b}}$ (in the context of $\mathrm{H}_{2}{ }^{\mathrm{z}}$ ) also resulted in increased expression of disease (27). Interestingly, in this study no linkage between the MHC and anti-dsDNA production was observed. In a separate backcross analysis, $\mathrm{H}_{2} \mathrm{v}$ appeared to be equivalent to $\mathrm{H} 2^{\mathrm{d}}$ in the effect on disease expression (29). Our results showing that $\mathrm{H} 2$ composition has an antigen-specific association with autoantibodies suggests that selective peptide presentation may be involved. It seems reasonable to propose that this involves peptides of the major serum gp70 glycoprotein, which has been sequenced recently (56).

One non-MHC locus on chromosome 14 (22 cM from the centromere) had suggestive linkage (Tables II $B$ and III $B$ ) with elevated levels of gp70 IC but showed no influence on any of the antinuclear antibodies measured. The specificity of the linkage suggests that the chromosome 14 locus (which is NZW recessive in the backcross studied) acts in an antigen-specific fashion. An interesting candidate locus in this region is the $\mathrm{T}$ cell receptor $\alpha$-chain (Tcra) complex, situated on chromosome $14, \sim 19 \mathrm{cM}$ from the centromere. The Tcra locus was previously examined in $(\mathrm{NZB} \times \mathrm{NZW}) \mathrm{F}_{1} \times \mathrm{NZB}$ backcross mice (21); no linkage with disease was identified, but gp70 IC levels were not studied. The possibility of gene interaction between the MHC and Tcra with anti-gp70 production was examined with MAPMAKER/QTL. The LOD score obtained using a two-QTL model $(\mathrm{LOD}=4.84)$ was below the sum of the indi- 
vidual Tcra and MHC loci ( $\Sigma$ LOD $=5.34$ in Table III $B)$, a result compatible with epistasis (43). It should be noted that mice in the current backcross analysis carried either one or two NZW TCR complexes. Compared with the NZB TCRA complex, the NZW complex is polymorphic at multiple TCRAV gene segments (57). It is also possible that the NZB complex is critically involved in a $\mathrm{T}$ cell response that decreases disease expression.

Several non-MHC loci were linked with elevated levels of antinuclear antibodies out of proportion to an effect on $\mathrm{gp} 70$ IC levels. Loci on chromosomes 7 and 16 appeared to influence both anti-DNA and antihistone antibody production, which is consistent with the hypothesis that these two specificities are controlled in a similar fashion. Previous studies have noted that antibodies to DNA and histone increase coordinately in $(\mathrm{NZB} \times \mathrm{NZW}) \mathrm{F}_{1}$ mice with age $(21,45)$. Furthermore, it has been proposed that a $\mathrm{T}$ cell response to a histone or other chromatin-derived peptide underlies the autoantibody response to both histone and DNA (58). Two loci with the strongest linkage with antinuclear antibody levels were an NZB locus on chromosome 7 (52 cM from the centromere) and an NZW locus on chromosome 16 (32cM from the centromere). A similarly positioned locus on chromosome 7 has been mapped as a disease susceptibility locus in a separate backcross study (29), and proximal loci on the same chromosome have been identified by others $(26,27)$.

The relative role of anti-gp70 versus anti-DNA autoantibodies in the pathogenesis of lupus nephritis in (NZB $\times$ $\mathrm{NZW}) \mathrm{F}_{1}$ mice remains controversial $(2,19,22,25,39,48)$. The results from our current genetic analysis strongly support an important role for autoantibodies to gp70. Thus, MHC type showed the strongest linkage with the development of severe renal disease, and this locus demonstrated a strong influence on gp70 IC but not anti-dsDNA antibodies. One other locus (on chromosome 14) also appeared to selectively affect levels of anti-gp70 autoantibodies. Although its linkage with nephritis was below our statistical cutoff, a trend $(P<0.05)$ was apparent. We cannot exclude the possibility that these loci also control a small but highly pathogenic subset of anti-DNA antibodies or other autoantibody specificity, but we believe that this is unlikely. Despite a powerful influence on anti-dsDNA and antihistone autoantibody production, loci on chromosomes 7 and 16 showed lesser influences on disease expression and gp70 IC levels. The above genetic analyses prompted us to directly investigate the association of serum levels of antidsDNA versus anti-gp70 autoantibodies with the development of renal disease, and only gp70 IC showed a highly significant association. There was a trend for higher serum anti-dsDNA antibody levels in diseased mice, but this did not reach statistical significance (Table IV).

These data do not preclude a role for anti-dsDNA antibodies in the pathogenesis of lupus nephritis. Firstly, it is possible that a small pathogenic subset of the antibodies are primarily responsible for the organ damage $(13,15)$ and that these were missed in our assays of serum autoantibody levels. Secondly, the dominant pathogenic autoantibody system (ANA or antigp70) may vary depending on the genetic background of the particular murine model of lupus studied. This may account for inconsistent results as regards the role of gp70 in previous studies. Furthermore, our previous analysis of $(\mathrm{NZB} \times \mathrm{SM} /$ J) $\mathrm{F}_{1} \times$ NZW backcross mice showed possible disease-associated genes on chromosomes 7 and 19 (29). Studies are in progress to determine whether these genetic contributions to disease expression can be explained at the level of anti-DNA antibody production.

Interestingly, the NZB locus on chromosome 4, Nbal, which has been confirmed to be linked with renal disease in this model (26-29), had a negligible influence on autoantibody production. No linkage was identified with antinuclear antibody specificities measured. A weak correlation between gp70 IC and the most distal marker on chromosome $4(76 \mathrm{cM})$ analyzed, was identified when 7 mo serological data were studied. This is unlikely to account for the disease linkage because the influence of Nbal on gp70 IC was not seen when peak gp70 IC levels were analyzed, or when a QTL analysis was performed, and the gp70 IC linkage was more distal than that with disease. As discussed above, we cannot exclude the possibility that Nbal affects the production of an unknown pathogenic autoantibody specificity or a small subset of pathogenic autoantibodies, perhaps involving a particular Ig subclass(es) (59). However, the data suggest that Nbal operates at a level distal to autoantibody production in the pathogenesis of lupus nephritis. Important contributions could affect the deposition or in situ formation of immune complexes in the glomeruli, influence the inflammatory response to glomerular immune complexes, or affect the kidney's sensitivity to the inflammatory processs. With respect to the chromosome 4 interval containing the disease-associated locus, a relevant example is the gene encoding the complement component, $\mathrm{Clq}$ (60), which could modulate immune complex formation or the local inflammatory response.

It should be emphasized that this study was not designed to be another mapping analysis of genetic contributions in murine lupus. Rather, we attempted to use mapping data in relation to subphenotypes to provide information about the mechanisms of disease. Together, our findings provide important new insight into the genetic control of lupus renal disease and into the immunopathogenesis of this disease. Although autoantibodies to gp70 are unlikely to play a major role in human lupus nephritis, our results emphasize the potential pathogenic importance of autoantibody specificities in addition to those directed to dsDNA.

\section{Acknowledgments}

We thank J.A. Todd for critically reading the manuscript and M. Greiner for secretarial assistance.

This work was supported by grant AR37070 from the National Institutes of Health (to B.L. Kotzin), a grant from the Lupus Foundation of America (to B.L. Kotzin and T.J. Vyse), and a grant from the Swiss National Foundation for Scientific Research to S. Izui. T.J. Vyse is the recipient of Travelling Fellowship from the Medical Research Council of Great Britain and a Fulbright Scholarship.

\section{References}

1. Howie, J.B., and B.J. Helyer. 1968. The immunology and pathology of NZB mice. Adv. Immunol. 9:215-266.

2. Theofilopoulos, A.N. 1992. Murine models of systemic lupus erythematosus. In Systemic Lupus Erythematosus. R.G. Lahita, editor. Churchill Livingstone, New York. 121-194.

3. Burnet, F.M., and M.C. Holmes. 1965. The natural history of the NZB/ NZW $F_{1}$ hybrid mouse: a laboratory model of human systemic lupus erythematosus. Australas. Ann. Med. 14:185-196.

4. Dixon, F.J., M.B.A. Oldstone, and G. Tonietti. 1971. Pathogenesis of the immune-complex glomerulonephritis of New Zealand mice. J. Exp. Med. 134(Suppl. 2):65S-71S. 
5. Lambert, P.H., and F.J. Dixon. 1968. Pathogenesis of glomerulonephritis of NZB/W mice. J. Exp. Med. 127:507-533.

6. Ebling, F., and B.H. Hahn. 1980. Restricted subpopulations of DNA antibodies in kidneys of mice with systemic lupus. Comparison of antibodies in serum and renal eluates. Arthritis Rheum. 23:392-403.

7. Hahn, B.H., and F.M. Ebling. 1987. Idiotype restriction in murine lupus: high frequency of three public idiotypes on serum IgG in nephritic NZB/NZW $\mathrm{F}_{1}$ mice. J. Immunol. 138:2110-2118.

8. Izui, S., P.H. Lambert, and P.A. Miescher. 1977. Failure to detect circulating DNA-anti-DNA complexes by four radioimmunological methods in patients with systemic lupus erythematosus. Clin. Exp. Immunol. 30:384-392.

9. Izui, S., P.H. Lambert, and P.A. Miescher. 1976. In vitro demonstration of a particular affinity of glomerular basement membrane and collagen for DNA. A possible basis for a local formation of DNA-anti-DNA complexes in systemic lupus erythematosus. J. Exp. Med. 144:428-443.

10. Bernstein, K.A., R. Di Valerio, and J.B. Lefkowith. 1995. Glomerular binding activity in MRL Ipr serum consists of antibodies that bind to a DNA/ histone/type IV collagen complex. J. Immunol. 154:2424-2433.

11. Schmiedeke, T., F. Stoeckl, S. Müller, Y. Sugisaki, S. Batsford, R. Woitas, and A. Vogt. 1992. Glomerular immune complex deposits in murine lupus models may contain histones. Clin. Exp. Immunol. 90:453-458.

12. Kramers, C., M.N. Hylkema, M.C. van Bruggen, R. van de Lagemaat, H.P.B.M. Dijkmann, K.J.M. Assmann, R.J.T. Smeenk, and J.H. Berden. 1994. Anti-nucleosome antibodies complexed to nucleosomal antigens show antiDNA reactivity and bind to rat glomerular basement membrane in vivo. J. Clin. Invest. 94:568-577.

13. Faaber, P., T.P. Rijke, L.B. Van de Putte, P.J. Capel, and J.H. Berden. 1986. Cross-reactivity of human and murine anti-DNA antibodies with heparan sulfate. The major glycosaminoglycan in glomerular basement membranes. $J$. Clin. Invest. 77:1824-1830.

14. Madaio, M.P., J. Carlson, J. Cataldo, A. Ucci, P. Migliorini, and O. Pankewycz. 1987. Murine monoclonal anti-DNA antibodies bind directly to glomerular antigens and form immune deposits. J. Immunol. 138:2883-2889.

15. Raz, E., M. Brezis, E. Rosenmann, and D. Eilat. 1989. Anti-DNA antibodies bind directly to renal antigens and induce kidney dysfunction in the isolated perfused rat kidney. J. Immunol. 142:3076-3082.

16. Yoshiki, T., R.C. Mellors, M. Strand, and J.T. August. 1974. The viral envelope glycoprotein of murine leukemia virus and the pathogenesis of immune complex glomerulonephritis in New Zealand mice. J. Exp. Med. 140: $1011-1125$

17. Izui, S., J.H. Elder, P.J. McConahey, and F.J. Dixon. 1981. Identification of retroviral gp70 and anti-gp70 antibodies involved in circulating immune complexes in NZB $\times$ NZW mice. J. Exp. Med. 153:1151-1160.

18. Hara, I., S. Izui, and F.J. Dixon. 1982. Murine serum glycoprotein gp70 behaves as an acute phase reactant. J. Exp. Med. 155:345-357.

19. Izui, S., P.J. McConahey, A.N. Theofilopoulos, and F.J. Dixon. 1979. Association of circulating retroviral gp70-anti-gp70 immune complexes with murine systemic lupus erythematosus. J. Exp. Med. 149:1099-1116.

20. Knight, J.G., D.D. Adams, and H.D. Purves. 1977. The genetic contribution of the NZB mouse to the renal disease of the NZB $\times$ NZW hybrid. Clin. Exp. Immunol. 28:352-358.

21. Kotzin, B.L., and E. Palmer. 1987. The contribution of NZW genes to lupus-like disease in $\left(\mathrm{NZB} \times \mathrm{NZW} \mathrm{F}_{1}\right.$ mice. J. Exp. Med. 165:1237-1251.

22. Maruyama, N., F. Furukawa, Y. Nakai, Y. Sasaki, K. Ohta, S. Ozaki, S. Hirose, and T. Shirai. 1983. Genetic studies of autoimmunity in New Zealand mice. IV. Contribution of NZB and NZW genes to the spontaneous occurrence of retroviral gp70 immune complexes in $(\mathrm{NZB} \times \mathrm{NZW}) \mathrm{F}_{1}$ hybrid and the correlation to renal disease. J. Immunol. 130:740-746.

23. Hirose, S., R. Nagasawa, I. Sekikawa, M. Hamaoki, Y. Ishida, H. Sato, and T. Shirai. 1983. Enhancing effect of H-2-linked NZW gene(s) on the autoimmune traits of $(\mathrm{NZB} \times \mathrm{NZW}) \mathrm{F}_{1}$ mice. J. Exp. Med. 158:228-233.

24. Babcock, S.K., V.B. Appel, M. Schiff, E. Palmer, and B.L. Kotzin. 1989. Genetic analysis of the imperfect association of $\mathrm{H}-2$ haplotype with lupus-like autoimmune disease. Proc. Natl. Acad. Sci. USA. 86:7552-7555.

25. Yoshida, H., A. Kohno, K. Ohta, S. Hirose, N. Maruyama, and T. Shirai 1981. Genetic studies of autoimmunity in New Zealand mice. III. Associations amoung anti-DNA antibodies, NTA, and renal disease in $(\mathrm{NZB} \times \mathrm{NZW}) \mathrm{F}_{1} \times$ NZW backcross mice. J. Immunol. 127:433-437.

26. Kono, D.H., R.W. Burlingame, D.G. Owens, A. Kuramochi, R.S. Balderas, D. Balomenos, and A.N. Theofilopoulos. 1994. Lupus susceptibility loci in New Zealand mice. Proc. Natl. Acad. Sci. USA. 91:10168-10172.

27. Morel, L., U.H. Rudofsky, J.A. Longmate, J. Schiffenbauer, and E.K. Wakeland. 1994. Polygenic control of susceptibility to murine systemic lupus erythematosus. Immunity. 1:219-229.

28. Drake, C.G., S.K. Babcock, E. Palmer, and B.L. Kotzin. 1994. Genetic analysis of the NZB contribution to lupus-like autoimmune disease in (NZB $\times$ NZW)F ${ }_{1}$ mice. Proc. Natl. Acad. Sci. USA. 91:4062-4066.

29. Drake, C.G., S.J. Rozzo, H.F. Hirschfeld, N.P. Smarnworawong, E. Palmer, and B.L. Kotzin. 1995. Analysis of the New Zealand Black contribution to lupus-like renal disease. Multiple genes that operate in a threshold manner. J. Immunol. 154:2441-2447.

30. Sambrook, J., E.F. Fritsch, and T. Maniatis. 1989. Molecular Cloning: A
Laboratory Manual. Cold Spring Harbor Laboratory Press, Cold Spring Harbor, NY. 9.22

31. Love, J.M., A.M. Knight, M.A. McAleer, and J.A. Todd. 1990. Towards construction of a high resolution map of the mouse genome using PCR-analysed microsatellites. Nucleic Acids Res. 18:4123-4130.

32. Dietrich, W.F., J. Miller, R. Steen, M.A. Merchant, D. Damron-Boles, Z. Husain, R. Dredge, M.J. Daly, K.A. Ingalls, T.J. O'Connor et al. 1996. A comprehensive map of the mouse genome. Nature (Lond.). 380:149-151.

33. Portanova, J.P., H.N. Claman, and B.L. Kotzin. 1985. Autoimmunization in murine graft-vs-host disease. I. Selective production of antibodies to histones and DNA. J. Immunol. 135:3850-3856.

34. Burlingame, R.W., and R.L. Rubin. 1990. Subnucleosome structures as substrates in enzyme-linked immunosorbent assays. J. Immunol. Methods. 133: 187-199.

35. Emlen, W., P. Jarusiripipat, and G. Burdick. 1990. A new ELISA for the detection of double-stranded DNA antibodies. J. Immunol. Methods. 132:91101

36. Kotzin, B.L., J.A. Lafferty, J.P. Portanova, R.L. Rubin, and E.M. Tan. 1984. Monoclonal anti-histone autoantibodies derived from murine models of lupus. J. Immunol. 133:2554-2559.

37. Izui, S., and G. Lange. 1983. Enzyme-linked immunosorbent assay for detection of retroviral gp70 and gp70-anti-gp70 immune complexes in sera from SLE mice. Clin. Exp. Immunol. 71:45-49.

38. Merino, R., L. Fossati, M. Lacour, R. Lemoine, M. Higaki, and S. Izui. 1992. H-2-linked control of the Yaa gene-induced acceleration of lupus-like autoimmune disease in BXSB mice. Eur. J. Immunol. 22:295-299.

39. Izui, S., P.J. McConahey, J.P. Clark, L.M. Hang, I. Hara, and F.J. Dixon. 1981. Retroviral gp70 immune complexes in NZB $\times$ NZW F $F_{2}$ mice with murine lupus nephritis. J. Exp. Med. 154:517-528.

40. Rosner, B. 1990. Hypothesis testing: categorical data. In Fundamentals of Biostatistics. PWS-KENT Publishing Co., Boston, MA. 318-396.

41. Lander, E.S., and D. Botstein. 1989. Mapping Mendelian factors underlying quantitative traits using RFLP linkage maps. Genetics. 121:185-199.

42. Paterson, A.H., E.S. Lander, J.D. Hewitt, S. Peterson, S.E. Lincoln, and S.D. Tanksley. 1988. Resolution of quantitative traits into Mendelian factors by using a complete RFLP linkage map. Nature (Lond.). 335:721-726.

43. Lincoln, S.E., M. Daly, and E.S. Lander. 1992. Mapping genes controlling quantitative traits with MAPMAKER/QTL 1.1. Whitehead Institute Technical Report. 2nd edition. Whitehead Institute, Cambridge, MA.

44. Lander, E., and L. Kruglyak. 1995. Genetic dissection of complex traits guidelines for interpreting and reporting linkage results. Nature Genet. 11:241247.

45. Gioud, M., B.L. Kotzin, R.L. Rubin, F.G. Joslin, and E.M. Tan. 1983. In vivo and in vitro production of anti-histone antibodies in NZB/NZW mice. $J$. Immunol. 131:269-274.

46. Bocchieri, M.H., A. Cooke, J.B. Smith, M. Weigert and R.J. Riblet. 1982. Independent segregation of NZB immune abnormalities in NZB $\times$ C58 recombinant inbred mice. Eur. J. Immunol. 12:349-354.

47. Miller, M.L., E.S. Raveché, C.A. Laskin, D.M. Klinman, and A.D. Steinberg. 1984. Genetic studies in NZB mice. IV. Association of autoimmune traits in recombinant inbred lines. J. Immunol. 133:1325-1331.

48. Shirai, T., O. Kiyoe, A. Kohno, F. Furukawa, H. Yoshida, N. Maruyama, and S. Hirose. 1986. Naturally occurring antibody response to DNA is associated with the response to retroviral gp70 in autoimmune New Zealand mice. Arthritis Rheum. 29:242-250.

49. Liblau, R.S., S.M. Singer, and H.O. McDevitt. 1995. Th1 and Th2 CD4+ $\mathrm{T}$ cells in the pathogenesis of organ-specific autoimmune diseases. Immunol. Today. 16:34-38.

50. Böhme, D., B. Schubaur, O. Kanagawa, C. Benoist, and D. Mathis 1990. MHC-linked protection from diabetes is not due to clonal deletion of T cells. Science (Wash. DC). 249:293-295.

51. Uno, M., T. Miyazaki, M. Uehira, H. Nishimoto, M. Kimoto, J.-I. Miyazaki, and K.-I. Yamamura. 1991. Complete prevention of diabetes in transgenic NOD mice expressing I-E molecules. Immunol. Lett. 31:47-52.

52. Cohen, P.L., E. Creech, D. Nakul-Aquaronne, R. McDaniel, S. Ackler, R.G. Rapoport, E.S. Sobel, and R.A. Eisenberg. 1993. Antigen nonspecific effect of major histocompatibility complex haplotype on autoantibody levels in systemic lupus erythematosus-prone lpr mice. J. Clin. Invest. 91:2761-2768.

53. Hirose, S., D. Zhang, S. Nozawa, H. Nishimura, and T. Shirai. 1994. The E-linked subregion of the major histocompatibility complex down-regulates autoimmunity in NZB $\times$ NZW $F_{1}$ mice. Immunogenetics. 40:150-153.

54. Wofsy, D., and W.E. Seaman. 1985. Successful treatment of autoimmunity in NZB/NZW $F_{1}$ mice with monoclonal antibody to L3T4. J. Exp. Med 161:378-391.

55. Gotoh, Y., H. Takashima, K. Noguchi, H. Nishimura, M. Tokushima, T. Shirai, and M. Kimoto. 1993. Mixed haplotype Aßz/A $\alpha$ d class II molecule in $(\mathrm{NZB} \times \mathrm{NZW}) \mathrm{F}_{1}$ mice detected by T cell clones. J. Immunol. 150:4777-4787.

56. Shigemoto, K., S. Kubo, Y. Itoh, G. Tate, S. Handa, and N. Maruyama. 1992. Expression and structure of serum gp70 as an acute phase protein in NZB mice. Mol. Immunol. 29:573-582.

57. Klotz, J.L., R.K. Barth, G.L. Kiser, L.E. Hood, and M. Kronenberg. 1989. Restriction fragment length polymorphisms of the mouse T-cell receptor 
gene families. Immunogenetics. 29:191-203.

58. Mohan, C., S. Adams, V. Stanik, and S.K. Datta. 1993. Nucleosome: a major immunogen for pathogenic autoantibody-inducing $\mathrm{T}$ cells of lupus. $J$. Exp. Med. 177:1367-1381.

59. Erausquin, C., R. Merino, S. Izui, L. Fernandez-Sueiro, F. Saez, F. Fernandez, V. Rodriguez-Valverde, and J. Merino. 1995. Therapeutic effect of early thymic irradiation in $(\mathrm{NZB} \times \mathrm{NZW}) \mathrm{F}_{1}$ mice, associated with a selective decrease in the levels of IgG3 and gp70-anti-gp70 immune complexes. Cell Immunol. 161:207-212.

60. McClive, P.J., and G. Morahan. 1994. Assignment of the mouse homologues of 6 loci to HSA1p to chromosomes 3 and 4. Genomics. 7:243-245. 